medRxiv preprint doi: https://doi.org/10.1101/2021.07.20.21260840; this version posted July 22,2021 . The copyright holder for this preprint

(which was not certified by peer review) is the author/funder, who has granted medRxiv a license to display the preprint in perpetuity.

All rights reserved. No reuse allowed without permission.

\title{
Will a natural collective immunity of Ukrainians restrain new COVID-19 waves?
}

\author{
Igor Nesteruk \\ Institute of Hydromechanics, National Academy of Sciences of Ukraine, Kyiv, Ukraine \\ Igor Sikorsky Kyiv Polytechnic Institute, Kyiv, Ukraine. \\ inesteruk@yahoo.com
}

\begin{abstract}
The visible and real sizes the COVID-19 epidemic in Ukraine were estimated with the use of the number of laboratory-confirmed cases (accumulated in May and June 2021), the generalized SIRmodel and the parameter identification procedure taking into account the difference between registered and real number of cases. The calculated optimal value of the visibility coefficient shows that most Ukrainians have already been infected with the coronavirus, and some more than once, i.e., Ukrainians have probably achieved a natural collective immunity. Nevertheless, a large number of new strains and short-lived antibodies can cause new pandemic waves. In particular, the beginning of such a wave, we probably see in Ukraine in mid-July 2021. The further dynamics of the epidemic and its comparison with the results of mathematical modeling will be able to answer many important questions about the natural immunity and effectiveness of vaccines.
\end{abstract}

Keywords: COVID-19 pandemic, epidemic dynamics in Ukraine, mathematical modeling of infection diseases, SIR model, parameter identification, statistical methods.

\section{Introduction}

The early stages of the COVID-19 pandemic outbreak in Ukraine were discussed in [1,2]. Further pandemic dynamics in this country was investigated with the use of the classical SIR model [3-5] and the statistics-based method of its parameter identification proposed in [6]. The results presented in [710] showed that this approach is able to predict only the first epidemic waves and only in the cases when the number of registered cases reflects the real one (fist predictions based on the initial datasets were two optimistic). Nevertheless, fairly accurate predictions about the first epidemic waves have been done for Italy, Austria, Germany, France, Spain, China, and South Korea [11].

The weakening of quarantine restrictions, changes in the social behavior and the coronavirus mutations caused changes in the epidemic dynamics and corresponding parameters of models. To detect these new epidemic waves, a simple method of numerical differentiations of the smoothed number of cases was proposed in [12, 13]. Predictions based on [3-6] for Ukraine, USA, UK, and the Republic of Moldova were not very reliable, since the second waves in these countries started before the finishing the first one [11]. To simulate different epidemic waves, the generalized SIR-model [14] and corresponding parameter identification procedure [15] were proposed. In particular, nine epidemic waves in Ukraine were calculated $[11,16,17]$.

NOTE: This preprint reports new research that has not been certified by peer review and should not be used to guide clinical practice.

Due to the large number of asymptomatic COVID-19 patients, the actual number of infected far exceeds the number of laboratory-confirmed cases, [18-23]. In order to assess the extent of data 
medRxiv preprint doi: https://doi.org/10.1101/2021.07.20.21260840; this version posted July 22, 2021. The copyright holder for this preprint (which was not certified by peer review) is the author/funder, who has granted medRxiv a license to display the preprint in perpetuity. All rights reserved. No reuse allowed without permission.

incompleteness, the identification algorithm for SIR-parameters was modified in [24, 25]. It allowed us to determine the true sizes of the COVID-19 epidemic in Ukraine [24-26] and in Qatar [27, 28]. In this paper we present the results of SIR simulations of the new pandemic wave in Ukraine based on the dataset for the number of cases registered in the period May 25 - June 7, 2021. The visible and real dimensions of the 11-th pandemic wave in Ukraine will be estimated and discussed.

Data

\begin{tabular}{|c|c|c|c|c|c|}
\hline $\begin{array}{c}\text { Day in } \\
\text { corres- } \\
\text { ponding } \\
\text { month of } \\
2021\end{array}$ & $\begin{array}{c}\text { Number } \\
\text { of cases } \\
\text { in } \\
\text { March, } \\
V_{j}\end{array}$ & $\begin{array}{c}\text { Number } \\
\text { of cases } \\
\text { in } \\
\text { April, } \\
V_{j}\end{array}$ & $\begin{array}{c}\text { Number } \\
\text { of cases } \\
\text { in } \\
\text { May, } \\
V_{j}\end{array}$ & $\begin{array}{c}\text { Number } \\
\text { of cases } \\
\text { in } \\
\text { June, } \\
V_{j}\end{array}$ & $\begin{array}{c}\text { Number } \\
\text { of cases } \\
\text { in } \\
\text { July, } \\
V_{j}\end{array}$ \\
\hline 1 & 1357470 & 1711630 & 2083180 & 2206836 & 2236497 \\
\hline 2 & 1364705 & 1731971 & 2085938 & 2209417 & 2237202 \\
\hline 3 & 1374762 & 1745709 & 2088410 & 2211683 & 2237579 \\
\hline 4 & 1384917 & 1755888 & 2090986 & 2213580 & 2237823 \\
\hline 5 & 1394061 & 1769164 & 2097024 & 2214517 & 2238364 \\
\hline 6 & 1401228 & 1784579 & 2105428 & 2215052 & 2238974 \\
\hline 7 & 1406800 & 1803998 & 2114138 & 2216654 & 2239591 \\
\hline 8 & 1410061 & 1823674 & 2119510 & 2218039 & 2240246 \\
\hline 9 & 1416438 & 1841137 & 2122327 & 2219824 & 2240753 \\
\hline 10 & 1425522 & 1853249 & 2124535 & 2221427 & 2241043 \\
\hline 11 & 1438468 & 1861105 & 2129073 & 2222701 & 2241217 \\
\hline 12 & 1451744 & 1872785 & 2135886 & 2223558 & 2241698 \\
\hline 13 & 1460756 & 1887338 & 2143448 & 2223978 & 2242245 \\
\hline 14 & 1467548 & 1903765 & 2150244 & 2224992 & 2242868 \\
\hline 15 & 1477190 & 1921244 & 2153864 & 2226037 & 2243605 \\
\hline 16 & 1489023 & 1936228 & 2156000 & 2227225 & 2244196 \\
\hline 17 & 1504076 & 1946510 & 2160095 & 2228192 & 2244495 \\
\hline 18 & 1519926 & 1953016 & 2165233 & 2229044 & 2244677 \\
\hline 19 & 1535218 & 1961956 & 2170398 & 2229523 & 2245275 \\
\hline 20 & 1546363 & 1974118 & 2175382 & 2229846 & - \\
\hline 21 & 1554256 & 1990353 & 2179988 & 2230142 & - \\
\hline 22 & 1565732 & 2004630 & 2182521 & 2230977 & - \\
\hline 23 & 1579906 & 2017341 & 2183855 & 2231914 & - \\
\hline 24 & 1596575 & 2025271 & 2186463 & 2232790 & - \\
\hline 25 & 1614707 & 2030333 & 2189858 & 2233546 & - \\
\hline 26 & 1632131 & 2038248 & 2193367 & 2233996 & - \\
\hline 27 & 1644063 & 2047838 & 2196673 & 2234281 & - \\
\hline 28 & 1652409 & 2059465 & 2199769 & 2234463 & - \\
\hline 29 & 1662942 & 2069537 & 2201472 & 2235096 & - \\
\hline 30 & 1674168 & 2078086 & 2202494 & 2235801 & - \\
\hline 31 & 1691737 & - & 2204631 & - & - \\
\hline & & & & & \\
\hline
\end{tabular}

Table 1. Cumulative numbers of laboratory-confirmed Covid-19 cases in Ukraine $V_{j}$ in the spring and summer of 2021 according to the national statistics, [29, 30]. 
medRxiv preprint doi: https://doi.org/10.1101/2021.07.20.21260840; this version posted July 22, 2021. The copyright holder for this preprint

(which was not certified by peer review) is the author/funder, who has granted medRxiv a license to display the preprint in perpetuity.

All rights reserved. No reuse allowed without permission.

We will use the data set regarding the accumulated numbers of laboratory-confirmed COVID-19 cases in Ukraine from national sources $[29,30]$. The corresponding numbers $V_{j}$ and moments of time $t_{j}$ (measured in days) are shown in Table 1. The values for the period $T_{c 10}$ : March 11-24, 2021 have been used in $[24,25]$ for SIR simulations of the tenth epidemic wave in Ukraine. Here we use the fresher dataset, corresponding to the period $T_{c 11}$ : May 23 - June 5, 2021 to simulate the 11-th wave. Other $V_{j}$ and $t_{j}$ values will be used to control the accuracy of predictions and pandemic dynamics.

\section{Generalized SIR model and parameter identification procedure}

The description of the generalized SIR-model and the exact solution of the set of non-linear differential equations relating the number of susceptible $S$, infectious $I$ and removed persons $R$ can be found in [14]. This solution uses the function

$$
V(t)=I(t)+R(t)
$$

corresponding to the number of victims or the cumulative confirmed number of cases. Its derivative:

$$
\frac{d V}{d t}=\alpha_{i} S I
$$

yields the estimation of the average daily number of new cases. When the registered number of victims $V_{j}$ is a random realization of its theoretical dependence (1), the exact solution presented in [14] depends on five parameters $\left(\alpha_{i}\right.$ is one of them). The details of the optimization procedure for their identification can be found in [15].

If we assume, that data set $V_{j}$ is incomplete and there is a constant coefficient $\beta_{i} \geq 1$, relating the registered and real number of cases during the $i$-th epidemic wave:

$$
V\left(t_{j}\right) \cong \beta_{i} V_{j}
$$

the number of unknown parameters increases by one. The procedure of their identification was presented in $[24,25]$. The values $V_{j}$, corresponding to the moments of time $t_{j}$ from the period March $11-24,2021$ have been used in $[24,25]$ to find the optimal values of these parameters corresponding to the tenth epidemic wave in Ukraine. In particular, the optimal value of the visibility coefficient $\beta_{10}=3.7$ was calculated. 
medRxiv preprint doi: https://doi.org/10.1101/2021.07.20.21260840; this version posted July 22, 2021. The copyright holder for this preprint

(which was not certified by peer review) is the author/funder, who has granted medRxiv a license to display the preprint in perpetuity. All rights reserved. No reuse allowed without permission.

\section{Monitoring changes in epidemic parameters and selection of epidemic waves}

Changes in the epidemic conditions (in particular, the peculiarities of quarantine and its violation, situations with testing and isolation of patients, emergence of new strains of the pathogen) cause the changes in its dynamics, i.e. so known epidemic waves. To control these changes we can use daily or weekly numbers of new cases and their derivatives (see, e.g., $[10,12,13])$. Since these values are random, we need some smoothing (especially for daily amounts, which are also characterized by some weekly periodicity). For example, we can use the smoothed daily number of accumulated cases:

$$
\bar{V}_{i}=\frac{1}{7} \sum_{j=i-3}^{j=i+3} V_{j},
$$

The first and second derivatives can be estimated with the use of following formulas:

$$
\begin{aligned}
& \left.\frac{d \bar{V}}{d t}\right|_{t=t_{i}} \approx \frac{1}{2}\left(\bar{V}_{i+1}-\bar{V}_{i-1}\right) \\
& \left.\frac{d^{2} \bar{V}}{d t^{2}}\right|_{t=t_{i}} \approx \bar{V}_{i+1}-2 \bar{V}_{i}+\bar{V}_{i-1}
\end{aligned}
$$

\section{Results and Discussion}

First we have used the number of laboratory-confirmed cases (accumulated in the period the period $T_{c 11}$ : May 23 - June 5, 2021 and presented in Table 1) for SIR simulations of the 11-th pandemic wave in Ukraine, i.e. we supposed that $\beta_{i}=1$ for $i=11$. The optimal values of parameters and other characteristics of this wave are calculated and listed in Table 2 (middle column). Comparison with the corresponding values for the tenth epidemic wave in Ukraine (see Table 2 in [25]) shows, that the optimal values of SIR parameters are very different for 11-th and 10-th pandemic waves. In particular, the estimations for the average time of spreading the infection $1 / \rho_{11}=4.1$ days (in comparison with $1 / \rho_{10}=22.3$ days for the tenth wave). The assessment of the 11-th epidemic wave duration (final day August 25, 2021 corresponding the moment when the number of infectious persons becomes less that unit) is very optimistic (compare to March 29, 2022 for tenth wave).

The difference in saturation levels (final sizes) are not so large $\left(V_{1100}=2,226,797\right.$ and $\left.V_{10 \infty}=1,783,175\right)$. As of July 18, 2021 the registered number of COVID-19 cases in Ukraine $(2,244,677)$ has already exceeded the saturation level of the eleventh epidemic wave. Since the difference recorded on day 43 after the last day of period used for the calculations $T_{c 11}$ is only $0.8 \%$, 
medRxiv preprint doi: https://doi.org/10.1101/2021.07.20.21260840; this version posted July 22,2021 . The copyright holder for this preprint

(which was not certified by peer review) is the author/funder, who has granted medRxiv a license to display the preprint in perpetuity. All rights reserved. No reuse allowed without permission.

we have another confirmation of the suitability of the generalized SIR-model for forecasting pandemic wave dynamics. The corresponding SIR curves (black lines), registered number of cases and the derivatives (5) and (6) (red markers) are shown in Fig. 1.

\begin{tabular}{|c|c|c|}
\hline Characteristics & $\begin{array}{c}11^{\text {th }} \text { epidemic wave, } \\
i=11, \\
\beta_{11}=1\end{array}$ & $\begin{array}{c}11^{\text {th }} \text { epidemic wave, } \\
i=11, \\
\beta_{11}=20.376\end{array}$ \\
\hline $\begin{array}{c}\text { Time period taken } \\
\text { for calculations } T_{c i}\end{array}$ & May 23-June 5, 2021 & May 23 - June 5, 2021 \\
\hline$I_{i}$ & $10,190.8327995721$ & $207,648.409124103$ \\
\hline$R_{i}$ & $2,180,167.16720043$ & $44,423,086.1988759$ \\
\hline$N_{i}$ & $2,258,464$ & 46018462.464 \\
\hline$v_{i}$ & $60,891.3982283695$ & $1,240,723.13030139$ \\
\hline$\alpha_{i}$ & $3.98540619731056 \mathrm{e}-06$ & $1.95593158486001 \mathrm{e}-07$ \\
\hline$\rho_{i}$ & 0.242676955862249 & 0.242676955862287 \\
\hline $1 / \rho_{i}$ & 4.12070440082342 & 4.12070440082277 \\
\hline$r_{i}$ & 0.996838194153353 & 0.996838194153390 \\
\hline$S_{i \infty}$ & 31,667 & 645,251 \\
\hline$V_{i \infty}$ & $2,226,797$ & $45,373,211$ \\
\hline Final day of the \\
epidemic wave
\end{tabular}

Table 2. Visible and real characteristics of the eleventh COVID-19 pandemic wave in Ukraine. Results of calculations for optimal values of SIR parameters and other characteristics

The jumps in values of the second derivative (6) shown in Fig. 1 by red "dots" illustrate the changes in the epidemic dynamics in the first half of May 2021 (probably connected with holidays). The values of the fist derivative (5) shown by red "crosses" are in good agreement with the theoretical estimation (2) (see black dotted line) for the period $T_{c 11}$ but deviate for the previous moments of time indicating significant changes in the epidemic dynamics. We can see also higher values of the first derivative (5) in comparison with estimation (2) (see black dotted line) after the period $T_{c 11}$. In particular, as of July 15, 2021 the estimation (5) yields value 13, but the average registered daily number of new cases (2) was 503. This fact and close to zero values of the second derivative (eq. (6), red "dots") probably indicate the beginning of a new epidemic wave. 
medRxiv preprint doi: https://doi.org/10.1101/2021.07.20.21260840; this version posted July 22, 2021. The copyright holder for this preprint (which was not certified by peer review) is the author/funder, who has granted medRxiv a license to display the preprint in perpetuity. All rights reserved. No reuse allowed without permission.

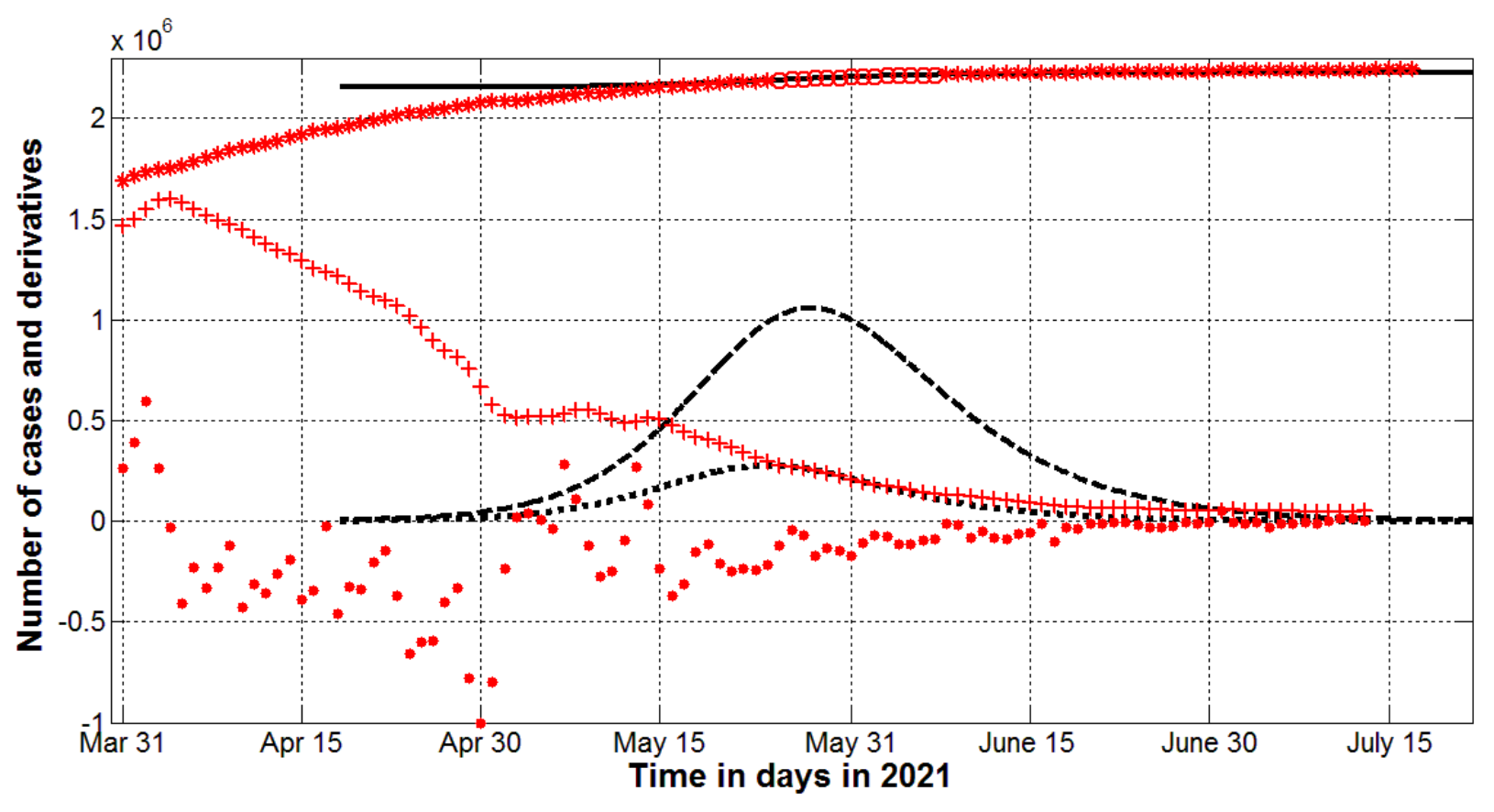

Fig. 1. Visible COVID-19 epidemic dynamics in Ukraine in the spring and summer of 2021. The results of SIR simulations of the eleventh wave at $\beta_{11}=1$ are shown by black lines. Numbers of victims $V(t)=I(t)+R(t)$ - solid lines; numbers of infected and spreading $I(t)$ multiplied by 100 - dashed; derivatives $d V / d t$ (eq. (2)) multiplied by 100 - dotted. Red "circles" and "stars" correspond to the accumulated numbers of cases registered during the period of time taken for SIR simulations (May 23 June 5, 2021, Table 1) and beyond this time period, respectively. The red "crosses" and "dots" show the first derivative (5) multiplied by 100 and the second derivative (6) multiplied by 1000, respectively.

Last column of Table 2 illustrates the results of SIR simulations with the non-prescribed value of $\beta_{i}$. The maximum of the correlation coefficient $r_{11}$ was achieved at $\beta_{11}=20.376$. Thus, the vast majority of COVID-19 cases in Ukraine have become invisible (the real accumulated number cases is probably approximately 20 times higher than registered one). The real final size of the eleventh epidemic wave $V_{11 \infty}$ is expected to be around 45.4 million and exceeds the population of Ukraine. If we multiply the number of registered cases $(2,244,677$ as of July 18,2021$)$ by the visibility coefficient $\beta_{11}=20.376$, the result 45.7 million is even higher. Probably, millions in Ukraine have already become re-infected and the nation achieved natural collective immunity (as of July 18, 2021 the percentage of fully vaccinated population was only $3.5 \%$ ).

If the calculated value of the visibility coefficient $\beta_{11}$ is correct, the mortality rate in Ukraine is not high. To estimate its value we can use the registered number of deaths $(52,726$ as of July 17, 2021). Probably, not all deaths caused by coronavirus have been reported, but in any case the visibility rate for them is lower than 20.376 due to the fact that critically ill patients usually go to hospitals and the corresponding deaths are properly recorded. Thus, the most optimistic estimation of the mortality rate is $52726 * 100 \% /(2244495 * 20.376)=0.12 \%$. 
medRxiv preprint doi: $h t t p s: / / d o i . o r g / 10.1101 / 2021.07 .20 .21260840$; this version posted July 22, 2021. The copyright holder for this preprint (which was not certified by peer review) is the author/funder, who has granted medRxiv a license to display the preprint in perpetuity. All rights reserved. No reuse allowed without permission.

As in the case of $\beta_{i}=1$, the optimal values of SIR model parameters are very different for tenth and eleventh epidemic waves (compare last columns in Table 2 and Table 3 from [25]). In particular, the differences are connected with the much higher value of the visibility coefficient ( $\beta_{11}=20.376$ in comparison with $\beta_{10}=3.7$ ). The optimistic prediction for the 11-th epidemic wave ending (September 20,2021) probably is not reliable since the beginning of a new epidemic wave is already visible in Fig.1). Ukrainians are also not guaranteed against the emergence or import of new coronavirus strains, which could cause new epidemic waves.

Optimal values of parameters presented in the last column of Table 2 allow us to calculate SIR curves corresponding to the real epidemic dynamics with the use of the exact solution presented in [14, 25]. The results are shown in Fig.2 by blue lines. The solid line represents complete accumulated number of cases (visible and invisible); the dashed line represents the complete number of infectious persons multiplied by 100 , i.e. $I(t) \times 100$; dotted black lines represent the derivative $d V / d t$ (which is an estimation of the real daily number of new cases) calculated with the use of (2) and multiplied by 100.

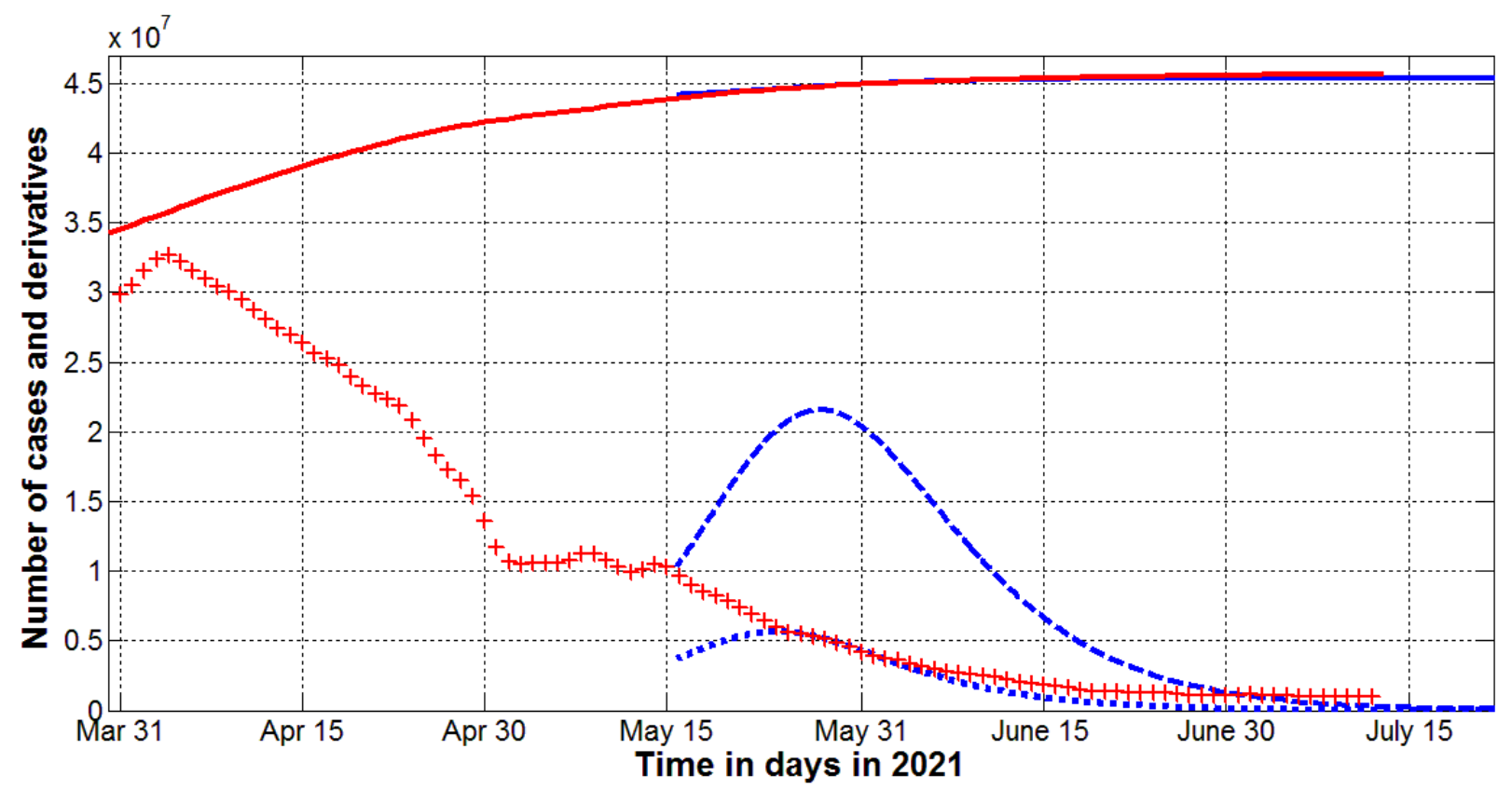

Fig. 2. Real COVID-19 epidemic dynamics in Ukraine in the spring and summer of 2021.

The results of SIR simulations of the eleventh wave at the optimal value $\beta_{11}=20.376$ are shown by blue lines. Numbers of victims $V(t)=I(t)+R(t)$ - solid lines; numbers of infected and spreading $I(t)$ multiplied by 100 - dashed; derivatives $d V / d t$ (eq. (2)) multiplied by 100 - dotted. The red solid line shows smoothed accumulated number of laboratory-confirmed cases (eq. (4)) multiplied by the optimal value $\beta_{11}=20.376$. The red "crosses" show the first derivative (5) multiplied by $100 \beta_{11}$.

Red "crosses" in Fig. 2 illustrate the estimation of the real average number of new daily cases for the eleventh wave, since the corresponding values were calculated by multiplying the derivative (5) by $100 \beta_{11}$. These values are in good agreement with the theoretical estimation (2) for the period $T_{c 11}$ (May 
medRxiv preprint doi: https://doi.org/10.1101/2021.07.20.21260840; this version posted July 22, 2021. The copyright holder for this preprint

(which was not certified by peer review) is the author/funder, who has granted medRxiv a license to display the preprint in perpetuity.

All rights reserved. No reuse allowed without permission.

23 - June 5, 2021) but deviate for the moments of time before and after this period (similar to the visible dynamics shown in Fig.1). The red line in Fig.2 represent the smoothed accumulated number of laboratory-confirmed cases (eq. (4)) multiplied by the optimal value of the visibility coefficient $\beta_{11}=20.376$ and is in very good agreement with the theoretical blue solid line.

The knowing of real sizes of the COVID-19 pandemic is very important to compare the effectiveness of vaccinations and a natural immunity. We can also estimate the probability of meeting an infected person with the use of simple formula, $[10,11]$ :

$$
p(t)=\frac{I(t)}{N_{p o p}}
$$

where $N_{\text {pop }}$ is the volume of population. As of July 19, 2021 the theoretical estimations (with the use of parameters presented in the last column of Table 2) yield the value $I=1656$ (see the blue dashed line in Fig. 2). Then the probability $p$ can be estimated as 0.00004 . This value is much lower than corresponding estimation 0.015 for the end of March 2021, [25]. If the situation does not worsen, Ukrainians will be welcome guests in many countries even without vaccination.

\section{Acknowledgements}

The author is grateful to Oleksii Rodionov for his help in collecting and processing data.

\section{References}

1. Nesteruk, I. "Comparison of the coronavirus pandemic dynamics in Ukraine and neighboring countries" [Preprint.] ResearchGate. 2020 Mar. doi: 10.13140/RG.2.2.31170.53448

2. Nesteruk, I., Kydybyn, I., Demelmair, G. GLOBAL STABILIZATION TRENDS OF COVID-19 PANDEMIC. KPI Science News, 2020, No. 2, pp. 55-62. DOI: 10.20535/kpi-sn.2020.2.205124

3. Kermack WO, McKendrick AG. A Contribution to the mathematical theory of epidemics. J Royal Stat Soc Ser A. 1927;115:700-21.

4. Murray JD. Mathematical Biology I/II. New York: Springer; 2002.

5. Langemann D, Nesteruk I, Prestin J. Comparison of mathematical models for the dynamics of the Chernivtsi children disease. Mathematics in Computers and Simulation. 2016;123:68-79. DOI: 10.1016/j.matcom.2016.01.003

6. Nesteruk I. Statistics based models for the dynamics of Chernivtsi children disease. Naukovi Visti NTUU KPI. 2017;5:26-34. DOI: 10.20535/1810-0546.2017.5.108577

7. Nesteruk, I. "Long-term predictions for COVID-19 pandemic dynamics in Ukraine, Austria and Italy" [Preprint.] MEDRXIV, 2020 Apr. doi: https://www.medrxiv.org/content/10.1101/2020.04.08.20058123v1

8. Nesteruk, I. “Як довго українці сидітимуть на карантині? How long will the Ukrainians stay in quarantine?” (in Ukrainian) [Preprint.] ResearchGate. 2020 April. doi: 10.13140/RG.2.2.15732.71046

9. Nesteruk I. Динаміка COVID-19 епідемії в Україні та Києві після покращання тестування. COVID-19 epidemic dynamics in Ukraine and Kyiv after testing has improved (In Ukrainian). [Preprint.] ResearchGate. 2020 Apr. DOI: 10.13140/RG.2.2.36705.86885 
medRxiv preprint doi: https://doi.org/10.1101/2021.07.20.21260840; this version posted July 22,2021 . The copyright holder for this preprint (which was not certified by peer review) is the author/funder, who has granted medRxiv a license to display the preprint in perpetuity. All rights reserved. No reuse allowed without permission.

10. Nesteruk I. Simulations and predictions of COVID-19 pandemic with the use of SIR model. Innov Biosyst Bioeng, 2020, vol. 4, no. 2, 110-121, doi: 10.20535/ibb.2020.4.2.204274. http://ibb.kpi.ua/article/view/204274

11. Nesteruk I. COVID-19 pandemic dynamics. Springer Nature, 2021, DOI: 10.1007/978-981-33-6416-5.

https://link.springer.com/book/10.1007/978-981-33-6416-5

12. Nesteruk I. Coronasummer in Ukraine and Austria. [Preprint.] ResearchGate. 2020 June. DOI:

10.13140/RG.2.2.32738.56002

13. Nesteruk I. Identification of the New Waves of the COVID-19 Pandemic. In book: COVID-19 Pandemic Dynamics, Springer Nature, 2021. DOI: 10.1007/978-981-33-6416-5_8. https://link.springer.com/chapter/10.1007/978-981-33-64165

14. Nesteruk I. General SIR Model and Its Exact Solution. In book: COVID-19 Pandemic Dynamics, Springer Nature, 2021. DOI: 10.1007/978-981-33-6416-5_9. https://link.springer.com/content/pdf/10.1007\%2F978-981-33-6416-5_9.pdf

15. Nesteruk I. Procedures of Parameter Identification for the Waves of Epidemics. In book: COVID-19 Pandemic Dynamics, Springer Nature, 2021. DOI: 10.1007/978-981-33-6416-5 10.

https://link.springer.com/chapter/10.1007\%2F978-981-33-6416-5_10

16. Nesteruk I., Benlagha N. PREDICTIONS OF COVID-19 PANDEMIC DYNAMICS IN UKRAINE AND QATAR BASED ON GENERALIZED SIR MODEL. Innov Biosyst Bioeng, 2021, vol. 5, no. 1, pp. 37-46. DOI:

10.20535/ibb.2021.5.2.230487 http://ibb.kpi.ua/article/view/230487

17. Nesteruk I. Detections and SIR simulations of the COVID-19 pandemic waves in Ukraine.

Comput. Math. Biophys. 2021;9:46-65. https://doi.org/10.1515/cmb-2020-0117

18. https://www.scmp.com/news/china/society/article/3076334/coronavirus-strange-pneumonia-seen-lombardy-novemberleading

19. Frankfurter Allgemeine. https://m.faz.net/aktuell/sport/mehr-sport/militaerweltspiele-2019-in-wuhan-damals-schoncorona-faelle-16758894.html

20. Weinberger DM et al. Estimating the early death toll of COVID-19 in the United States. [Preprint.] MEDRXIV, 2020 Apr. https://doi.org/10.1101/2020.04.15.2006643

21. https://edition.cnn.com/2020/11/02/europe/slovakia-mass-coronavirus-test-intl/index.html

22. https://www.voanews.com/covid-19-pandemic/slovakias-second-round-coronavirus-tests-draws-large-crowds

23. https://podillyanews.com/2020/12/17/u-shkolah-hmelnytskogo-provely-eksperyment-z-testuvannyam-na-covid-19/

24. Nesteruk I. Visible and real sizes of the COVID-19 pandemic in Ukraine.[Preprint] Research Gate,

March 2021. DOI: 10.13140/RG.2.2.12124.72322

https://www.researchgate.net/publication/350157247_Visible_and_real_sizes_of_the_COVID-19_pandemic_in_Ukraine

25. Nesteruk I. Visible and real sizes of new COVID-19 pandemic waves in Ukraine Innov Biosyst Bioeng, 2021, vol. 5, no. 2, pp. 85-96. DOI: $10.20535 / \mathrm{ibb} .2021 .5 .2 .230487$

http://ibb.kpi.ua/article/view/230487

26. Nesteruk I. Visible and real dynamics of the COVID-19 pandemic in Ukraine in the spring of 2021. [Preprint] MedRxiv, June 2021. DOI:10.1101/2021.06.13.21258838

27. Nesteruk I. Impact of vaccination and undetected cases on the COVID-19 pandemic dynamics in Qatar in 2021.

[Preprint] MedRxiv, May 2021. DOI: 10.1101/2021.05.27.21257929

28. Nesteruk I. Forecast verifications for the real COVID-19 pandemic dynamics in Qatar. [Preprint] MedRxiv, June 2021. DOI:10.1101/2021.06.16.21259018

29. https://index.minfin.com.ua/ua/reference/coronavirus/ukraine/

30. https://www.kmu.gov.ua/ 